\title{
Trochicola japonicus sp. nov., a Mytilicolid Copepod Parasitic in the Short Neck Clam (Tapes philippinarum) from Lake Hamana, Japan
}

\author{
Shigeru Shimura and Ren Kuwabara \\ Department of Fisheries, Faculty of Agriculture, University of \\ Tokyo, Yayoi, Bunkyo-ku, Tokyo 113, Japan
}

(Received October 12, 1983)

\begin{abstract}
A new mytilicolid copepod, Trochicola japonicus, parasitic in the intestine of the short neck clam, Tapes philippinarum, from Lake Hamana (semi-enclosed coastal bay) is described for both female and male.
\end{abstract}

\section{Introduction}

Trochicola Dollfus 1914 is a genus of mytilicolid copepods parasitic in marine molluscs. Four species of Trochicola have been hitherto described from European trochid topshells and scallops: $T$. entericus from Calliostoma zizyphinum, Gibbula cineraria, G. varia and Monodonta mutabilis (Dollfus 1914, 1927; Bocquet and STOCK, 1957a, b; Stock, 1960; KLeEton, 1963), $T$. pectinidarum from Pecten opercularis and $P$. glaber (TuzET and ORMIÈRES, 1961), T. vermiformis from G. magus (Sтоск, 1959) and Trochicola sp. from G. richardi (Sтоск, 1960).

The present paper describes the fifth species of Trochicola, T. japonicus, from the short neck clam, Tapes philippinarum, found in Lake Hamana, Japan.

\section{Material examined}

92 females and 9 males were discovered from the intestine of 75 Tapes philippinarum collected from Lake Hamana (map reference: $34^{\circ} 45^{\prime} \mathrm{N}, 137^{\circ} 35^{\prime} \mathrm{E}$ ) between June 24,1981 to April 10, 1982.

The holotype (female) NSMT-Cr 8923, allotype (male) NSMT-Cr 8924, paratypes (females only) NSMT-Cr 8925, 8926 have been deposited in the National Science Museum, Tokyo. Other paratypes (females only) MPM. Coll. No. 19383 have been deposited in the Meguro Parasitological Museum, Tokyo.

\section{Description of the Species \\ Trochicola japonicus sp. nov.}

Female:

Body (Fig. 1) elongated, 5.7-7.7 mm long, and nearly cylindrical. Color in life yellowish to reddish orange. Six pairs (1 cephalic and 5 somatic) of dorsolateral processes on body but without distinct tagmatization.

Head (Fig. 2) 0.33-0.43 mm long and 0.37$0.56 \mathrm{~mm}$ wide (excluding posterolateral processes), with a median and a pair of lateral ribs on dorsal surface; median dorsal rib bifurcated at posterior end and joined with lateral ribs on either side. Thorax 4.3-5.9 $\mathrm{mm}$ long and $0.49-0.66 \mathrm{~mm}$ wide (at genital segment). Genital segment slightly swollen laterally at the area of egg sac attachment. Egg sac whitish orange, 2.9-4.3 $\mathrm{mm}$ long and $0.27-0.34 \mathrm{~mm}$ wide, containing about $70-130$ eggs in each sac. Egg globular, 0.13-0.16 mm in diameter. Abdomen indistinctly 3-segmented, slightly tapering posteriorly, and measuring $0.98-1.24 \mathrm{~mm}$ long and $0.27-0.37$ $\mathrm{mm}$ wide at anterior end. Caudal ramus (Fig. 3) conical, measuring $0.15-0.20 \mathrm{~mm}$ long and $0.10-0.14 \mathrm{~mm}$ wide at base; each ramus bearing 4 knobs ( 1 lateral, 2 terminal and 1 dorsal). and rows of spinules on ventral surface.

First antenna (Fig. 4) 4-segmented; basal segment largest bearing 14 setae: 9 spiniform and 5 slender; armature of remaining 3 small segments as follows: 5,3 and 8 . No aesthetes 


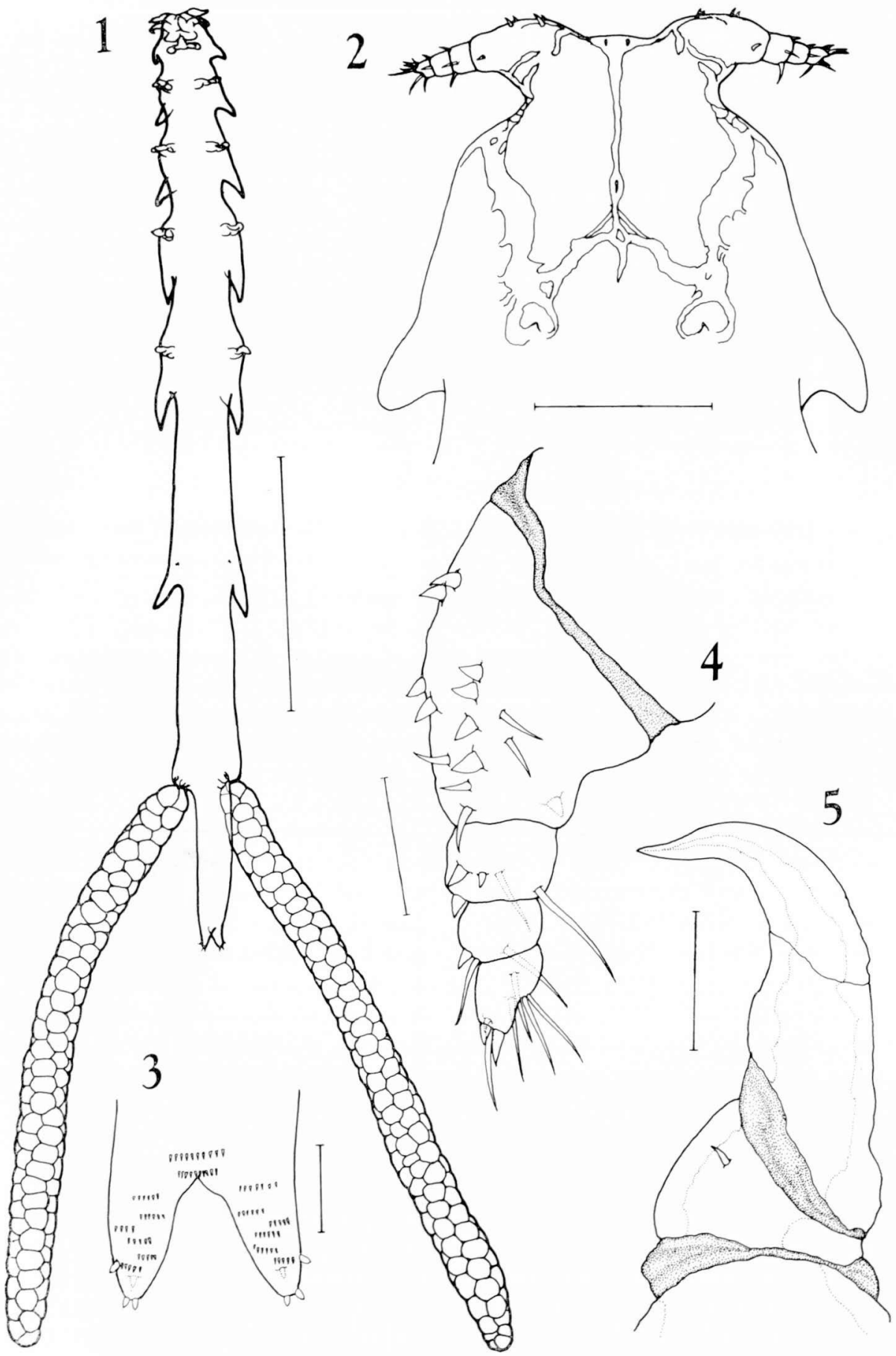

Trochicola japonicus sp. nov., female. Fig. 1. Habitus, ventral (scale: $2 \mathrm{~mm}$ ). Fig. 2. Head, dorsal $(0.2 \mathrm{~mm})$. Fig. 3. Caudal rami, ventral $(0.1 \mathrm{~mm})$. Fig. 4. First antenna, ventral $(0.05 \mathrm{~mm})$. Fig. 5. Second antenna, ventral $(0.05 \mathrm{~mm})$. 

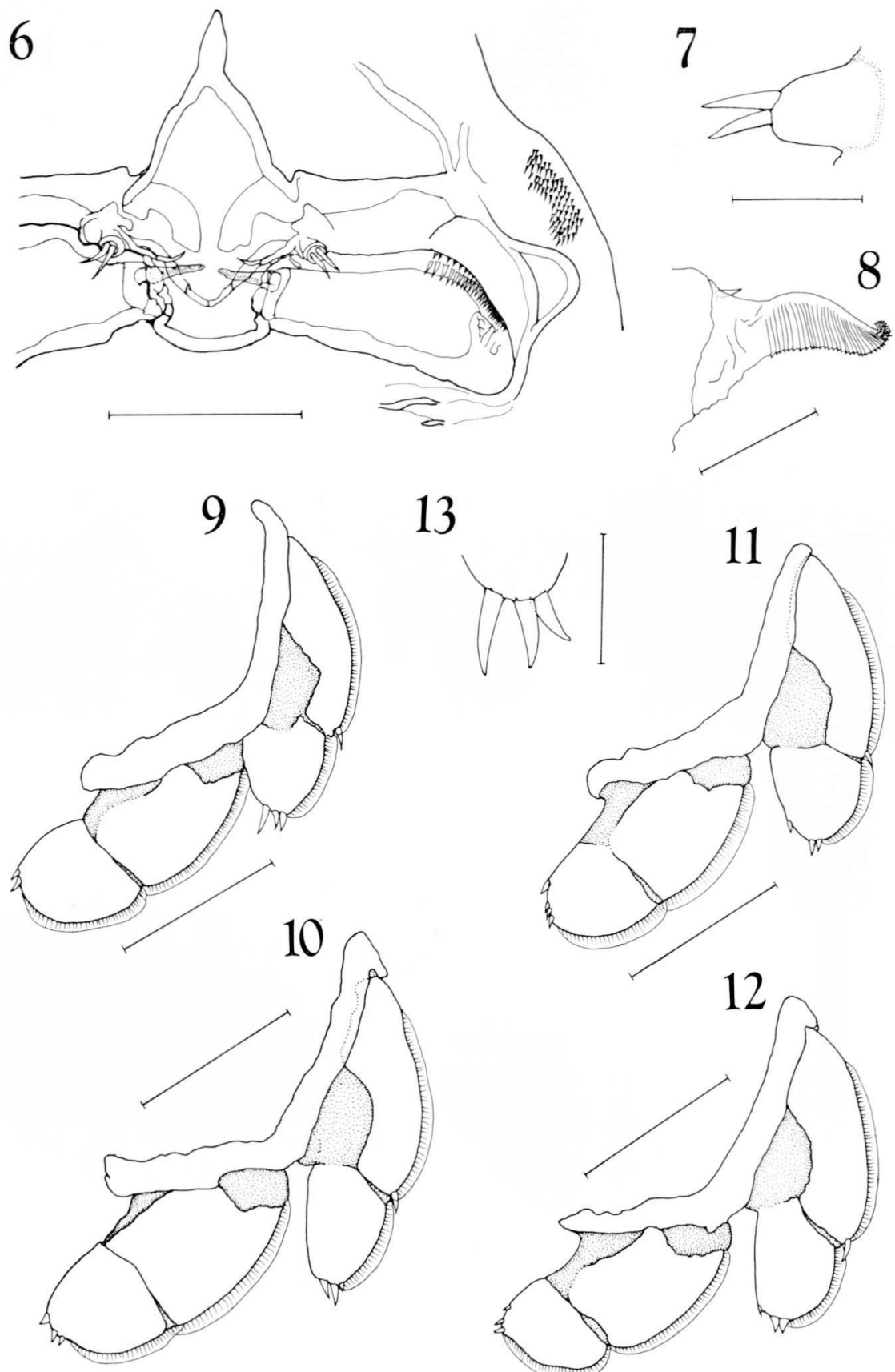

13
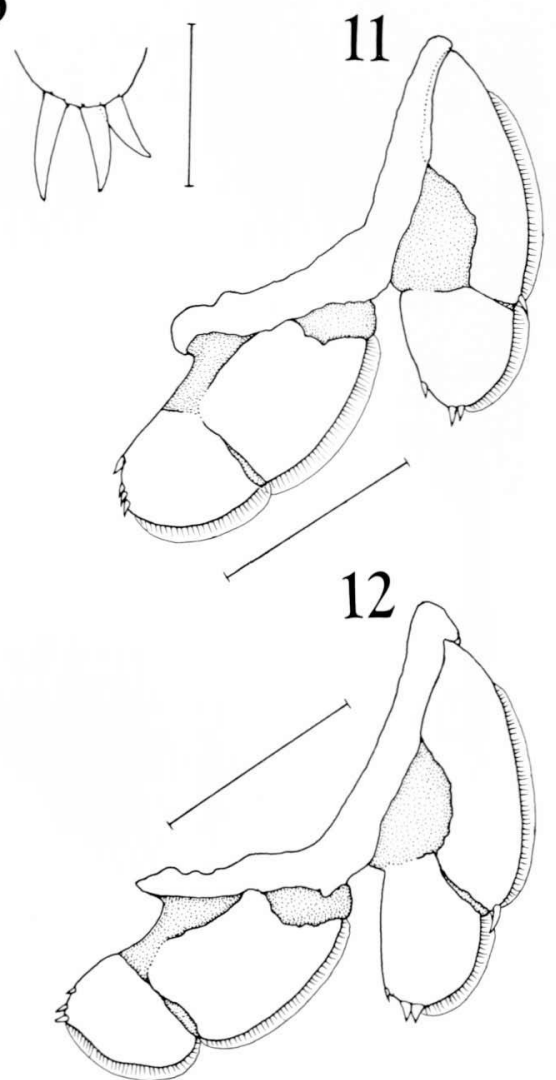

Trochicola japonicus sp. nov., female (continued). Fig. 6. Mouth-parts (scale: $0.1 \mathrm{~mm}$ ). Fig. 7. First maxilla $(0.03 \mathrm{~mm})$. Fig. 8. Tip of second maxilla $(0.03 \mathrm{~mm})$. Fig. 9. Leg 1, ventral $(0.1$ $\mathrm{mm})$. Fig. 10. Leg 2, ventral $(0.1 \mathrm{~mm})$. Fig. 11. Leg 3, ventral $(0.1 \mathrm{~mm})$. Fig. 12. Leg 4, ventral $(0.1 \mathrm{~mm})$. Fig. 13. Leg 5, ventral $(0.03 \mathrm{~mm})$. 

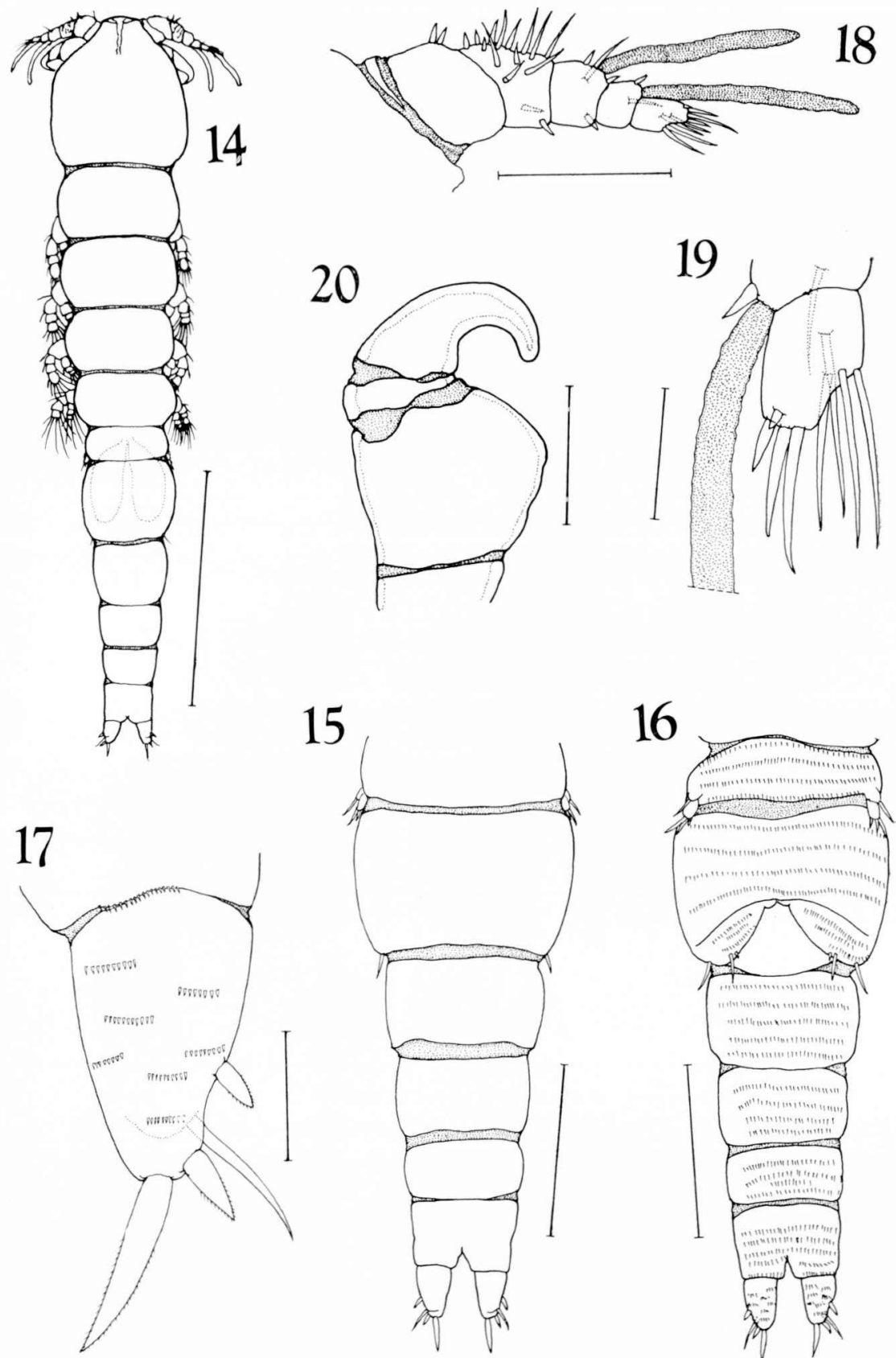

15
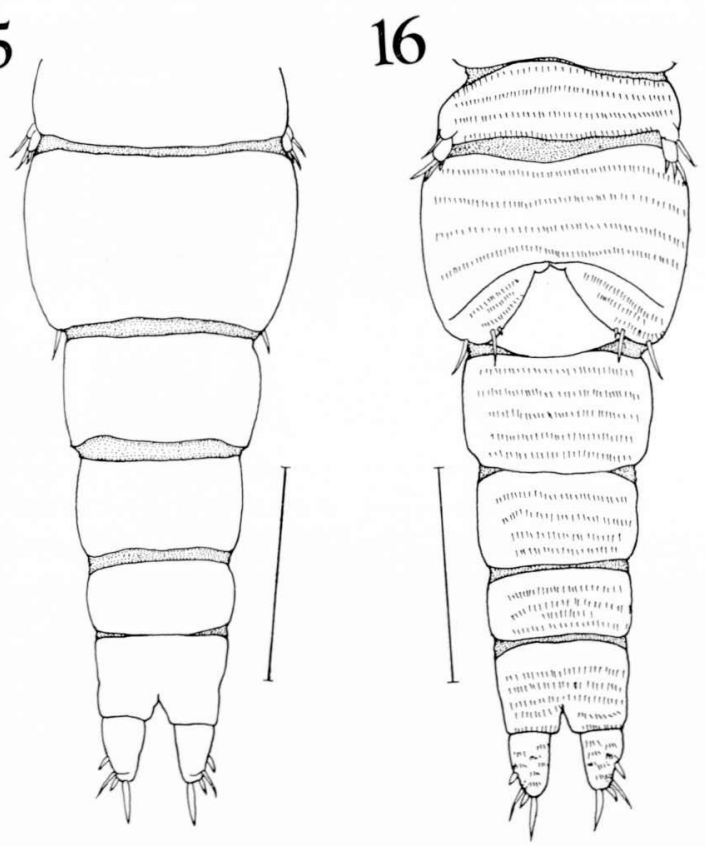

Trochicola japonicus sp. nov., male. Fig. 14. Habitus, dorsal (scale: $0.5 \mathrm{~mm}$ ). Fig. 15. Urosome, dorsal $(0.2 \mathrm{~mm})$. Fig. 16. Urosome, ventral $(0.2 \mathrm{~mm})$. Fig. 17. Caudal ramus, ventral $(0.03$ $\mathrm{mm})$. Fig. 18. First antenna, ventral $(0.1 \mathrm{~mm})$. Fig. 19. Tip of first antenna $(0.03 \mathrm{~mm})$. Fig. 20. Maxilliped $(0.03 \mathrm{~mm})$. 

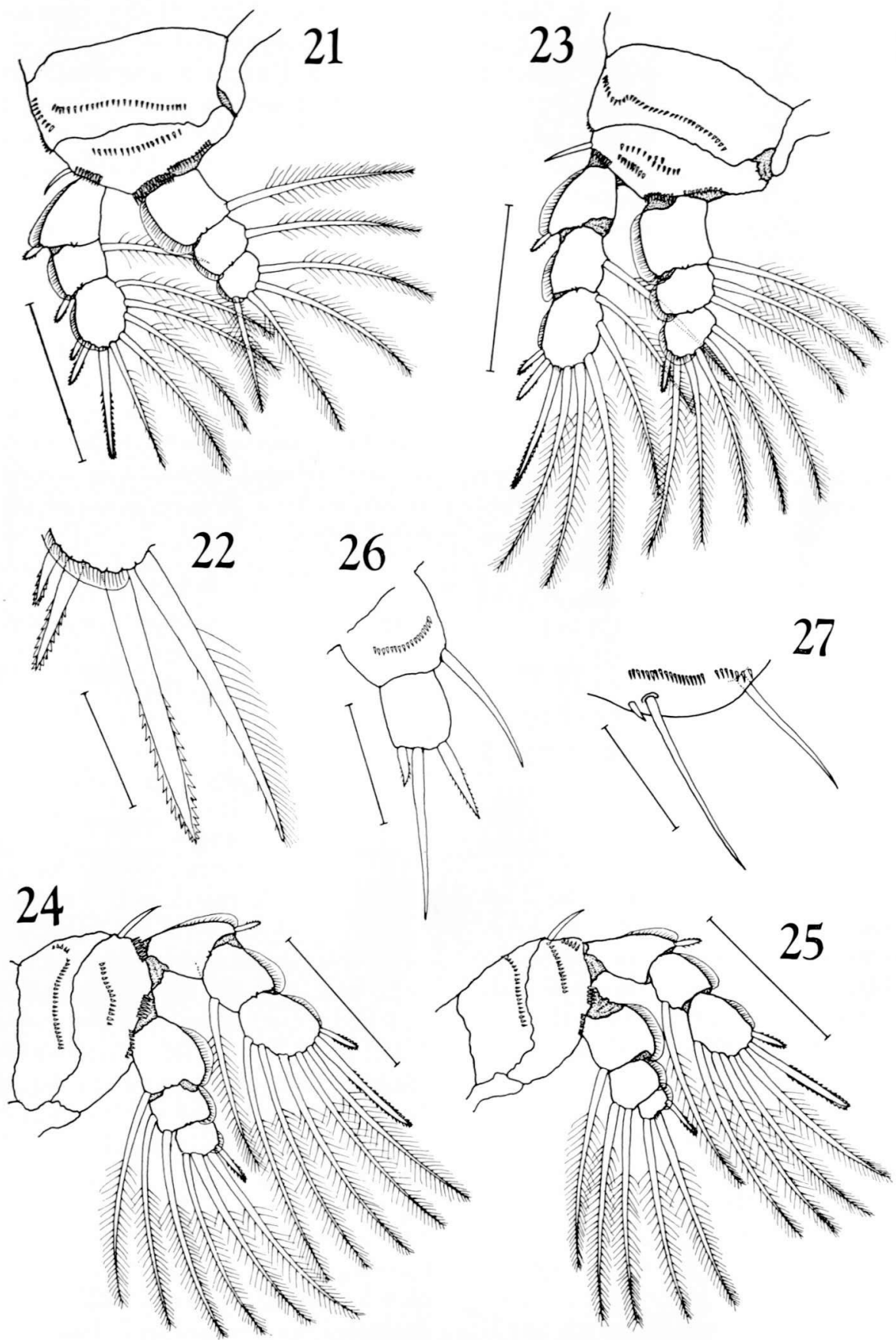

Trochicola japonicus sp. nov., male (continued). Fig. 21. Leg 1, ventral (scale: 0.1 mm). Fig. 22. Leg 1, terminal spines of exopod $(0.1 \mathrm{~mm})$. Fig. 23. Leg 2, ventral $(0.1 \mathrm{~mm})$. Fig. 24. Leg 3 , ventral $(0.1 \mathrm{~mm})$. Fig. 25. Leg 4, ventral $(0.1 \mathrm{~mm})$. Fig. 26. Leg 5, ventral $(0.03 \mathrm{~mm})$. Fig. 27. leg 6, ventral $(0.03 \mathrm{~mm})$. 
identified. Second antenna (Fig. 5) 4-segmented; second segment with 1 short seta near posterior margin and distal segment being a stout curved claw.

Labrum (Fig. 6) a plate with deep central incision. Labium (Fig. 6) elliptical and medially flattened. Mandible absent. First maxilla (Figs. 6 and 7) papilliform and tipped with 2 setae. Second maxilla (Figs. 6 and 8) 2-segmented; basal segment elongated, framed with wide chitinous thickenings, and pectinated at anterolateral margin; attenuated distal segment transversely striated and bearing 1 small basal seta. Maxilliped absent.

Legs 1-4 (Figs. 9-12) biramous. All rami 2-segmented; each segment with a flange on outer margin. Armature of these legs as follows:

\begin{tabular}{lll} 
& \multicolumn{1}{c}{ exopod } & \multicolumn{1}{c}{ endopod } \\
Leg $11_{\text {i, }}$ & I-0, III & $0-0,0$ to III \\
Leg 2 & I-0, II or III & $0-0$, III to V \\
Leg 3 & I-0, II or III & $0-0$, II to V \\
Leg 4 & I-0, I to III & $0-0,0$ to IV
\end{tabular}

Leg 5 (Fig. 13) a minute process bearing 3 terminal spiniform setae.

Male:

Body (Fig. 14) elongated, with distinct tagmatization but remarkably smaller than female, measuring only $1.24-1.46 \mathrm{~mm}$ long. Cephalothorax $0.27-0.30 \mathrm{~mm}$ long and $0.27-$ $0.28 \mathrm{~mm}$ wide. All somites in urosome with rows of ventral spinules (Fig. 16). Genital segment (Figs. 15 and 16) barrel-shaped with distinct posteroventral genital ridge. $\mathrm{Ab}$ domen (Figs. 15 and 16) short, 4-segménted and measuring $0.28-0.35 \mathrm{~mm}$ long and 0.14-0.16 $\mathrm{mm}$ wide. Caudal ramus (Fig. 17) cylindrical, 0.05-0.06 mm long and 0.03-0.04 mm wide, and carrying 4 setae: 1 lateral fringed, 2 terminal unequal and fringed, and 1 dorsal slender and naked.

First antenna (Figs. 18 and 19) 5-segmented; formula on these segments as follows: 2,15 , $4+1$ aesthete, $2+1$ aesthete, and 8 . Second antenna and mouth-parts as in female. Maxilliped (Fig. 20) consisting of a robust basal segment and a terminal curved bluntly pointed claw.
Legs 1-4 (Figs. 21-25) biramous; each protopod 2-segmented with rows of spinules; basis with 1 outer naked seta. All rami 3segmented; each segment with a flange on outer margin. Formula of spines (Roman numerals) and setae (Arabic numerals) as follows:

$$
\text { exopod endopod }
$$

$\begin{array}{lll}\text { Leg 1 } & \text { I-0; I-1; III, 5 } & 0-1 ; 0-1 ; 4 \\ \text { Leg 2 } & \text { I-0;0-1; III, 5 } & 0-1 ; 0-2 ; \text { I, 5 } \\ \text { Leg 3 } & \text { I-0;0-1; II, 5 } & 0-1 ; 0-2 ; \text { I, 3 } \\ \text { Leg 4 } & \text { I-0;0-1; II, 4 } & 0-1 ; 0-2 ; \text { I, 2 }\end{array}$

Leg 5 (Fig. 26) uniramous and 2-segmented; basal segment with 1 slender naked seta and distal free segment with 1 slender naked and 2 short fringed setae. Leg 6 (Fig. 27) represented by 2 slender, unequal setae and 1 basal spine.

\section{Remarks}

The Japanese species is characterized by the following features: (1) female first antenna 4-segmented, (2) bearing a pair of cephalic processes, (3) male maxilliped without membrane in terminal claw, (4) male leg 5 with 3 setae in distal free segment, and (5) male caudal ramus with short setae. The female of $T$. entericus has 5-segmented first antenna, but lacks cephalic processes (DoLlfus, 1914). The male of $T$. entericus has a membrane in the terminal claw of its maxilliped, leg 5 has 2 setae in distal segment and the elongated cylindrical caudal ramus has setae, one of which is very long (BOcQUET and STOcK, 1957). The female iof $T$. pectinidarum resembles that of $T$. entericus but the male has wider metasomal somites, larger genital segment and short cylindrical caudal ramus (TUzET and ORMIÈres, 1961). The female of $T$. vermiformis is tremendously elongated and the male is not different from $T$. entericus (Sтоск, 1959). Therefore, the Japanese species is clearly distinguishable from all the described species and so is treated as a new species.

\section{Acknowledgements}

We wish to thank to Mr. T. T. Do, Ocean Research Institute, University of Tokyo, for his helpful assistance and suggestion in the 
description of the species, to Professor J. S. Ho, Department of Biology, California State University, Long Beach, for his critical review of the manuscript, and to $\mathrm{Mr}$. $\mathrm{H}$. FUshimi, Shizuoka Prefectural Fisheries Experimental Station, for his kind assistance in the collection of the clams.

\section{References}

BocQuet, C. and J. H. Stock (1957a): Copépodes parasites d'invertébrés des côtes de France. II. Notes taxonomiques et écologiques sur la famille des Mytilicolidae. Proc. Koninkl. Nederl. Akad. Wetensch. Amsterdam, Ser. C, 60, 223-232.

Bocquet, C. and J. H. STocK (1957b): Copépodes parasites d'invertébrés des côtes de France. III. Notes taxonomiques et écologiques sur la famille des Mytilicolidae. Proc. Koninkl.

Nederl. Akad. Wetensch. Amsterdam, Ser. C,
60, 233-239.

Dollfus, R. P. (1914): Trochicola enterica nov. gen. nov. sp., eucopépode parasite de l'intestin des troques. C.R. Hebd. Seanc. Acad. Sci., Paris, 158, 1528-1531.

Dollfus, R. P. (1927): Notules sur les copepodes parasites de la faune française (I-III). Bull. Soc. Zool. Fr., 52, 119-121.

KLeEton, G. (1961): New host and distribution record of the copepod Trochicola entericus. Crustaceana, 3, 172.

Stock, J. H. (1959): Copepoda associated with Neapolitan Mollusca. Pubbl. Staz. Zool. Napoli, 31, 43-58.

Srock, J.H. (1960): Sur quelques copépodes associés aux invertébrés des côtes du Roussillon. Crustaceana, 1, 218-257.

TUZET, O. and R. ORMIÈRES (1961): Trochicola pectinidarum n. sp., copépode (Mytilicolidae) parasite de Pecten opercularis (L.) et Pecten glaber (L.). C.R. Congr. Soc. Sav., 86, 697-701.

\title{
浜名湖産アサリに寄生する橈脚類の 1 新種 Trochicola japonicus
}

\author{
志村 茂*.桑原 連* \\ (昭和 58 年 10 月 12 日受理)
}

浜名湖産アサリの消化管内に寄生する Mytilicolidae 科の橈脚類を検出し，これを新種と認めて，Trochicola japonicusと 命名し，記載した。 